\title{
SUCROSE CONTENT OF SUGARCANE AS AFFECTED BY MOTH-BORER, DIATRAEA SACCHARALIS (FABRICIUS), INFESTATION ${ }^{1}$
}

\author{
Luis F. Martorell and Ishver S. Bangdiwala ${ }^{2}$
}

INTRODUCTION

The sugarcane moth stalk-borer, Diatraea saccharalis (Fabricus), has been and still is the most important sugarcane insect pest in Puerto Rico. Early reports on the attack of this insect appeared in a publication by Fernando López Tuero $(4)^{3}$ in 1895 . As translated from the Spanish, he wrote:

If the injury of the insect were confined to the cane which it destroys, it would not be so serious but the galleries which it constructs give access to the air, and the juice of the cane in the region of the wounds becomes subject to the usual ferments, communicating the fermentation from particle to particle in the juice and from fibre to fibre, until the juice of the cane is totally or to a great degree changed.

In the older abandoned plantations the ravages of the borer are likely to be so great as to make it useless to harvest the crop. Even though some of the stalks remain sound, selection during cutting would not be practical, and, if the injured cane is sent to the mill, the altered juice will corrupt all of the juice and will produce a sugar of the lowest grade.

L. D. Van Dine (7) in 1912, writing about the damages of the borer said:

The effect of the borer injury on the cane juice is only one of the several losses the planter suffers from this pest. The destruction of the inner tissues of the stalk causes a loss in weight and retards the growth. Where the cane is heavily infested, many stalks will be rendered worthless and will, of necessity, be discarded when harvesting

${ }^{1}$ This work would not have been possible without the cooperation of Luce \& Co.' Aguirre, P. R. To all the personnel of Luce \& Co., which cooperated in these investigations the writers are most grateful, particularly to M. S. Baker, In Charge of Agricultural Research Department; C. H. Burleigh, Agronomist, Research Department; T. B. Fraser, Field Manager, Cortada Division; and Néstor Ramos, Assistant Field Manager, Cortada Division. The writers appreciate the assistance given to them in their fieldwork by Wilfredo Cruz and Gaspar Rivera. Thanks are given to B. G. Capó and G. N. Wolcott for reading, criticism, and suggestions in preparing this paper. The writers are also indebted to Leonardo Igaravidez, Assistant Chemist, for his careful analysis of the sugarcane juices at the Chemistry Laboratory and to A. Cruz Miret, who cooperated in the statistical calculations in this work. Juan L. Moreno, of the Department of Entomology, and Esther Pérez of the Agricultural Extension Service, are responsible for the figures. Félix Román and Edmundo Silva of the Department of Agricultural Economics, helped in supplying information given in table 5 .

2 Entomologist and Assistant Statistician, respectively, Agricultural Experiment Station, University of Puerto Rico, Río Piedras, P. R.

${ }^{3}$ Numbers in parentheses refer to Literature Cited, pp. 36-7. 
the crop, giving a lower tonnage. The stand is reduced in plant cane by the nongermination of eyes that have been injured by the borer in the cuttings used as seed. The stand of cane is further reduced in both plant and ratoon crops by the young shoots that are killed out by the destruction of the "heart" by the young borers. The wounds in the stalk caused by the borer offer an entrance to diseases and consequent decay. There is greater difficulty in grinding borer-infested canes for the reason that the juice is decreased and the fibre increased and the stalks are proportionally harder. Borer-infested stalks are easily broken by the wind and by the laborers in working the crop.

The attack of the borer in the sugarcane stalks is supposed to produce indirect losses in sucrose content by opening the way of entrance to rot organisms, such as fungi and bacteria, capable of producing chemical reactions which invert the sugar, thus lowering the sucrose content of the canes.

Our study dealt only with the direct losses of available sucrose in the juices as affected by the borer, disregarding all other losses caused by the insect in the fields.

\section{PAST INVESTIGATIONS}

It would be very difficult to cite all the previous investigations related to the losses in sucrose content and purity of the juice from the attack of the moth-borer on sugarcane. Probably the first investigation of this kind in Puerto Rico was made in 1911, by D. L. Van Dine, Entomologist for the Experiment Station of the Sugar Producer's Association of Porto Rico. Van Dine summarized his work (7) as follows:

There is a direct loss in sugar and decided reduction in the purity of the juice of cane infested by the moth stalk-borer. This loss in Porto Rico exceeded 670 pounds of sugar per acre of cane in which the infestation was not apparent except upon examination, the yield averaging 41 tons of cane per acre and the stalks being normal and healthy in appearance. The loss increases in direct proportion to the number of joints of the cane stalks infested by the borer. There is more fibre and less juice in borer infested cane. The actual weight of borer infested cane is less than that of sound cane and it is considered that the juice deteriorates more rapidly in infested cane when cane is allowed to stand without being crushed for any length of time after harvest.

Earlier than this were the reports of Stubbs and Morgan (6) from the Louisiana Agricultural Experiment Station in 1902. These investigators reported a loss in weight due to the borer of 4.98 tons of cane per acre, the average yield falling from 23.39 to 18.41 tons per acre. The factory loss was estimated to be 25 pounds of sugar per ton of cane harvested. These data were obtained from general averages of the records of one factory for 11 years during which the plantation was comparatively free from borer infestation and for 3 years of borer attack, on an area of 3,227 acres. The average loss in weight from the decrease in yield amounted to 16,061 
tons of cane per year and the average loss in sugar as a result of the borer injury on the cane juice amounted to 741 tons of sugar per year. Thus, the figures indicated a field loss of 16,041 tons of cane and a further factory loss of 741 tons of sugar per year for this one plantation.

During the year 1910, T. C. Barber (1), carrying on investigations at Audubon Park, New Orleans, La., regarding the injury to cane juice by the moth-borer, also obtained results on the direct losses in sucrose as affected by borer attack. Mr. Barber summarized his experiments as follows:

It should be noted as having a bearing on all of these analyses that the lower the purity of the juice the lower is the percentage of total sucrose that is recoverable in the form of sugar. Therefore the percentage loss of sugar in the impure samples somewhat exceeds the loss of sucrose. The sucrose which can not be recovered is approximately equal in amount to the glucose present. On this basis the present experiment would show a production of 176.26 pounds of sugar per ton for the borer-free cane, while the borer-infested cane would give 138.97 pounds of sugar, a loss of 37.29 pounds per ton of cane, equaling a loss of 21.16 per cent sugar, which is 1.83 per cent in excess of the sucrose loss.

It may be computed from the figures in Table VII that an acre of borer-free cane yielding 25 tons of cane of the above quality would yield $4,716.25$ pounds of sucrose per acre, while if it were infested to the same degree by borers, the yield under similar conditions would be 23.92 tons of cane and $3,637.75$ pounds of sucrose per acre-a loss of $1,078.50$ pounds sucrose per acre.

For many years agricultural investigators have been working on the moth-borer problem in the State of Louisiana. In 1945, Ingram and Dugas (3) reported on the losses resulting from sugarcane-borer injury to cane. Among other things revealed in their investigation, they said:

A summary of the results for 1945 together with those for the entire period during which these surveys have been conducted, is given in table 1. It may be noted that the estimated average percentage of joints bored in 1945 was 16.5 as compared with 13.9 in 1944 and an average of 15.2 for the period of the survey, 1935-1945. However, the 1945 average was lower than for 1941, 1942 or 1943.

The value of the 1945 Louisiana sugarcane crop to the grower was estimated at $\$ 35,660,000$ by the Bureau of Agricultural Economics of the U. S. Department of Agriculture in its December 26, 1945, report. Careful observations indicate the percentage of sucrose lost because of the borer to be about one-half the percentage of joints bored, and the loss due to reduction in weight of cane delivered to the mill to be one-half the sucrose loss. Thus, with an average of 16.5 percent of the joints bored the borer caused a loss of 12.375 percent, or nearly $\$ 5,000,000$, to Louisiana sugar farmers in 1945 .

One of the latest studies was carried on in Cuba, at the Experimental Station of Central Gomez Mena by J. G. Salinas (5) who concluded that: "The borer has caused damages equivalent to $\$ 0.74$, as an average per each 100 'arrobas' of cane (2,500 pounds) ground during the harvesting season of 1949." 
During the same year J. W. Ingram, E. K. Bynum, and others (2) at the Houma Laboratories in Louisiana, investigating the sugarcane-borer situation in Louisiana, found the following:

On an average 22.5 percent of the joints were found bored in a systematic survey of borer injury conducted at harvesttime in 1949, in representative Louisiana cane fields by the Houma Laboratory, in cooperation with the Louisiana Agricultural Experiment Station. This percentage is much higher than the average of 14.3 percent of joints bored during the period 1935-48 and is the highest infestation observed since the present method of survey was initiated in 1935. On the basis of data indicating a loss of 0.5 percent of total sucrose for each 1 percent of joints bored and a loss in weight of 0.25 percent for each 1 percent of joints bored, it is estimated that the crop loss in 1949 amounted to 16.8 percent. By applying this percentage of loss to the preliminary estimate on a 39 million dollar sugarcane crop in 1949 by the Louisiana Crop Reporting Service, it is estimated that the sugarcane borer caused a loss of over 7 million dollars in the State in 1949.

A study having as its objective the determination of the effects of the borer injury on sugarcane stalks in terms of the direct loss of sucrose in the cane juices, was started during the spring of 1950 .

\section{SAMPLING AREA USED}

Sugarcane samples were collected from the following colonias, all the property of Luce \& Co., S. en C.: Juana Díaz, Amelia, Centro, Florida, and Potala. These colonias are in a group covering an area of several thousand acres from El Pastillo, near Losey Field in the west up to the outskirts of the town of Santa Isabel in the east. The area studied is fairly representative of the south coast of Puerto Rico, as far as rainfall, humidity, and other conditions are concerned.

The work, which covered a period of two harvesting seasons-1950 and 1951, included the following number of fields studied in the different colonias: Amelia, 5 fields; Florida, 2 fields; Potala, 1 field; Centro, 3 fields, and Juana Díaz, 9 fields. Over 1,000 cane samples were collected in the 20 fields under study.

\section{PROCEDURE}

\section{Collection of Samples}

Cane stalks were collected at random from the fields under study which were going to be harvested 3 or 4 days after the collection, thus assuring perfect maturity of the cane. Usually 200 or 300 whole cane stalks were collected at random from each field. The laborers, six or eight in number, were trained to perform this work as accurately as possible in order to obtain representative samples of the fields studied. The cane was cut as close to the ground and as close to the top as possible to include top joints also in our investigations. The percentage of borer infestation was estimated by 
dividing the total number of joints bored by the total number of joints (including the bored ones) in the 10 canes included in each sample. In this way was obtained what is termed the "percentage of bore-infested joints."

\section{Classification of Samples}

The sugarcane stalks collected in the fields by the method described were classified into bored and nonbored stalks.

Whole-stalk samples (stalks cut at the base close to the soil and topped where the terminal bud is located) were classified in two groups: Bored, and nonbored or healthy canes as they were called in the field. For example, if 200 or 300 canes were collected from field No. 12, the bored canes were first separated from the nonbored ones. If 150 canes out of 200 were bored, 15 samples (10 canes each) of bored canes and 5 of nonbored or healthy canes could be made. The percentage of infestation on each sample was recorded after careful determination. These field data were accurately recorded on especially prepared field blanks. The samples were identified by numbers and letters so as to determine the identity of those that had to be taken from the field to the laboratory for grinding and analyzing the juices. A very simple system of labelling the samples were followed which avoided confusion or rarely led to a mistake in their further identification once they were out of our control.

Canes collected at Colonia Juana Díaz, from field No. 12 , were labelled as follows: J.D. $-12-\mathrm{H}-1$; J.D. $-12-\mathrm{H}-2$; J.D. $-12-\mathrm{H}-3$, etc., thus indicating that the samples originated in that Colonia and in field No. 12, the H standing for healthy cane, the last number being the sample number. If the samples were from the bored canes, the same system was followed, but a B was used instead of the $\mathrm{H}$ to indicate bored canes. The different samples originating in different colonias were then easy to identify by using J. D. for Juana Díaz; P. for Potala; F. for Florida; C. for Centro, and A. for Amelia. More than 1,000 samples were handled in this way without losing track of any. These were always identified on the laboratory sheets once the analysis of the juices was delivered from the Chemistry Department. The samples were tied in three places with a very strong twine, and two label cards were tied to each sample giving the exact identification number.

Other whole-cane samples were taken and subdivided into tops, centers, and bases as follows: 400 or 500 canes were collected at random from a field and separated into healthy and bored classifications.

Center, top, and base samples were obtained from the healthy canes by taking samples of 10 healthy canes and then dividing these systematically into tops, centers, and bases. The samples were well tied up with strong twine, and properly labelled for sending to the laboratory.

Infested tops, centers, and bases were obtained also from the bored 
canes. Separate samples of these tops, centers, and bases were made, 8 to 10, to each sample. The percentage of bore-infested joints was determined and recorded for each sample. These were then labelled and packed following more or less the same system as was used with the whole-cane samples.

The division of whole canes into tops, centers, and bases, was made in order to determine the loss of sucrose, if any, caused directly by the mothborer infestation in the different sections of the cane as well as in the whole cane. On the south coast of Puerto Rico the highest percentage of joints infested is invariably found in the top of the stalks. The lowest borer infestation is usually at the base or bottom of the cane. The reason for these differences in borer infestation will be explained subsequently.

The top was regarded as the four or five joints close to the terminal bud in the stalk. The top is really the green or immature part of the stalk, the number of joints varying according to the cane variety. The base of the cane is made up of the lower four or five bottom joints; in many long canes this base or bottom extends up to seven or eight joints. The center is usually the longest sample, including 8 to 10 or more joints at times.

The senior writer has not only used this system of classification in the determination of bore-infested joints for this particular study, but also in 4 years of investigations on the moth-borer at the south coast of Puerto Rico. The percentage of borer infestation of the fields under study has been recorded in these three ways as well as the total percentage of joint and of stalk infestation. This system of determination has provided very. interesting facts related to the borer which the authors hope to present and discuss in future publications.

The samples thus collected, labelled, and packed were taken from the south coast to the Río Piedras laboratory daily, so that the canes were ground and the juice analyzed from 15 to 24 hours after harvest. At the Río Piedras laboratory the samples were ground in a Squier hydraulic mill. The juice extracted from each sample was collected and weighed and a representative sample immediately sent to the chemistry laboratory where it was analyzed with little loss of time. The same procedure was followed with the samples of this study in the fields, the mill, and the laboratory.

ESTIMATION OF THE EFFECT OF MOTH-BORER INFESTATION

To estimate the effect of the moth-borer infestation on the sucrose content of sugarcane, the nonbored and bored samples were considered together, the whole data falling into four distinct classes, i.e., samples from the whole cane, the tops, the centers, and the bases.

The study of the regression of the percentage sucrose content of the cane on the percentage infestation was made separately for each of these four classifications. 
TABLE 1.-Regression coefficients for whole-cane samples, 1950-51

\begin{tabular}{|c|c|c|c|}
\hline \multicolumn{2}{|c|}{ Year 1950} & \multicolumn{2}{|c|}{ Year 1951} \\
\hline Field identification No. & Regression coefficient ${ }^{1}$ & Field identification No. & Regression coefficien $\mathrm{t}^{\mathrm{t}}$ \\
\hline & & 2 & $-0.1293^{* *}$ \\
\hline & & 3 & $.1393^{* *}$ \\
\hline 1 & -0.03175 & 4 & .03012 \\
\hline 2 & $.02818^{*}$ & 10 & $.07496 * *$ \\
\hline 3 & .02246 & 11 & .02505 \\
\hline 7 & .02944 & 12 & .006222 \\
\hline 9 & $.03110 *$ & 15 & .01416 \\
\hline 16 & .02584 & 16 & .01670 \\
\hline 22 & $.05239 *$ & 18 & .02522 \\
\hline 23 & $.02853^{*}$ & 19 & .05331 \\
\hline 27 & .03945 & 30 & .01342 \\
\hline Average & $-0.03280^{* *}$ & & $-0.03679^{* *}$ \\
\hline $\begin{array}{l}\text { Average regression } \\
\text { coefficient for } \\
\text { whole cane }\end{array}$ & & & $-0.03549^{* *}$ \\
\hline
\end{tabular}

$1 * *$ Probability level of significance: 1 percent; * probability level of significance: 5 percent.

\section{Whole Cane}

The data for the study of whole-cane infestation were available from 360 samples (each sample of 10 canes, making a total of 3,600 canes) selected at random over a period of two crop seasons from 20 different fields in the area mentioned above. On the assumption of existence of a linear relation between the available sucrose and the degree of infestation, the trend of the regression was studied for each of the fields separately, and the regression equations were obtained. The coefficients of regression are given in table 1 .

The effect of infestation on sucrose was observed to be detrimental in all the field samples. The range of the percentage decrease in sucrose was from 0.006 to 0.139 per 1-percent increase in infestation. Out of the 20 fields studied for whole-cane infestation, 8 showed evidence of significant effect. On testing these regression coefficients for homogeneity, however, it was found that they did not differ significantly from one another. This test led to estimating the average effect of infestation for whole cane over all the fields. Therefore, after eliminating the variation arising from the differences in the fields and that from the differences in the periods over which the samples were collected, the average estimation equation ob- 


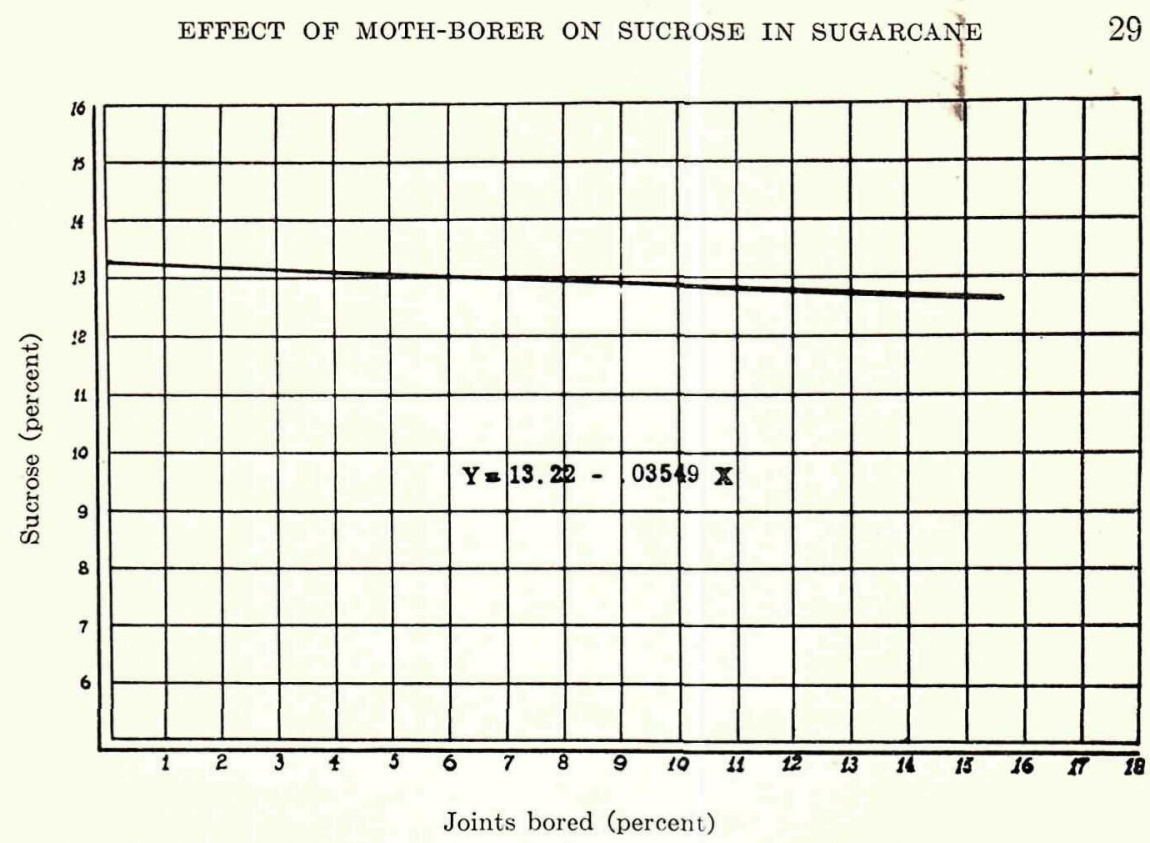

FIG. 1.-Line of regression of available sucrose in whole-cane on percentage infestation by moth-borers.

tained for the whole-cane infestation was:

$$
Y=13.22-0.035+9 X
$$

where $Y=$ percentage of available sucrose in whole cane, and $X=$ percentage borer infestation of whole cane.

On the average a 1-percent increase in infestation was found to reduce the sucrose content of whole cane by about 0.035 percent. This linear coefficient of regression was, on test, found to have a very high significant difference from zero. The regression line is shown in figure 1 .

The samples for the year 1950 showed this effect to be only 0.033 percent, while for the year 1951-was 0.037 for every 1-percent increase in infestation of the whole cane. The field coefficients for each year did not show significant differences among themselves.

\section{Tops}

A study similar to the one for whole-cane samples was made for the samples collected from tops of the sugarcane. One hundred and twentyeight samples (usually 8 to 10 tops to the sample, or over 1,200 tops) were available from 13 different fields from the same area, during one crop only. 
TABLE 2.-Regression coefficients for samples from sugarcane tops

\begin{tabular}{c|c|c|c}
\hline Field identification No. & Regression coefficient ${ }^{1}$ & Field identification No. & Regression coefficient ${ }^{1}$ \\
\cline { 1 - 3 } 1 & -0.009989 & 25 & -0.01729 \\
5 & .05438 & 26 & .04036 \\
8 & $.03721^{* *}$ & 28 & $.07975^{* *}$ \\
9 & .01166 & 29 & $.08304^{*}$ \\
17 & $.07407^{*}$ & 32 & .01306 \\
20 & .009598 & 33 & .03846 \\
22 & .2508 & & $-0.03904^{* *}$ \\
\hline Average regression & & & \\
coefficient for & & & \\
tops & & & \\
\hline
\end{tabular}

1 ** Probability level of significance: 1 percent; * probability level of significance: 5 percent.

The regression equations were obtained for each of these fields, on the same assumption of linear relationship as for the whole cane. The coefficients of regression are shown in table 2 . It is clear that the infestation also had a detrimental effect on the sucrose content of the cane tops in all the fields. The effect, however, varied from field to field, ranging from essentially -0.0096 to -0.251 percent for 1 percent of infestation. Four of these coefficients were found to be significant.

In spite of these wide fluctuations in the intensity of the detrimental effect in different fields, their regression coefficients failed to show sufficient evidence of difference among themselves. Hence, the average regression of the percentage of sucrose for tops on the percentage infestation was computed after eliminating the variation due to the differences in the fields only, there being no variation due to differences in time, as the samples for tops were all collected at once. The regression equation was:

$$
Y=9.33-0.03904 X
$$

where $Y=$ percentage of available sucrose in tops, and $X=$ percentage of borer infestation in tops, showing that the effect of infestation in tops was to reduce the sucrose content by 0.039 percent for every 1 -percent increase in borer infestation. Figure 2 shows the estimated average regression line fitted to data for the tops. Like the average regression coefficient for whole cane, the coefficient for tops also was found to be highly significant as compared with the zero effect.

\section{Centers}

The data for infestation in sugarcane centers were derived from 188 random samples ( 8 to 10 centers to a sample, or over 1,800 centers) from 14 


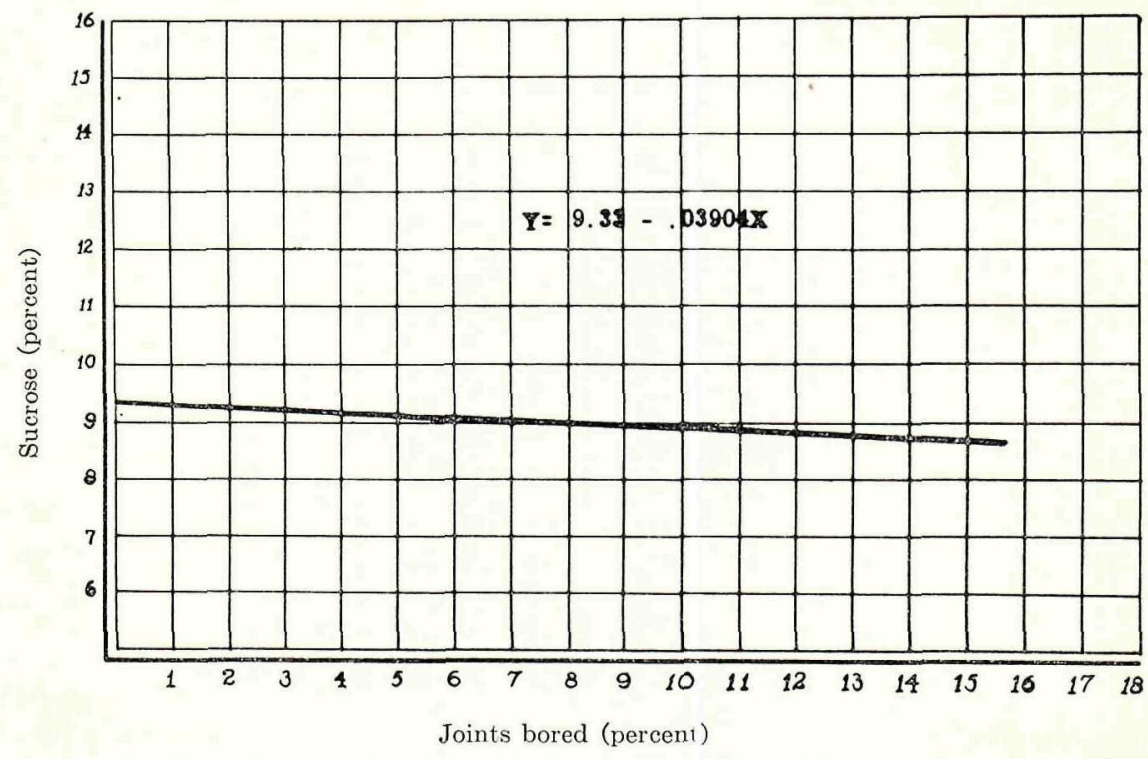

Fig. 2.-Line of regression of available sucrose in tops of cane on percentage infestation by moth-borers.

TABLE 3.-Regression coeffcients for samples from sugarcane centers

\begin{tabular}{|c|c|c|c|}
\hline Field identification No. & Regression coefficien $t^{1}$ & $\begin{array}{l}\text { lield identification } \\
\text { No. }\end{array}$ & Regression coefficient \\
\hline $\begin{array}{r}6 \\
8 \\
13 \\
17 \\
20 \\
21 \\
24\end{array}$ & $\begin{array}{c}-0.08892^{* *} \\
.07673^{* *} \\
.04662 \\
.08049 * \\
.04057 \\
.04718 \\
.05315\end{array}$ & $\begin{array}{l}25 \\
26 \\
28 \\
29 \\
31 \\
32 \\
33\end{array}$ & $\begin{array}{c}-0.005013 \\
.08430^{* *} \\
.05776^{*} \\
.02814 \\
.05906^{*} \\
.05650^{*} \\
.02422\end{array}$ \\
\hline $\begin{array}{l}\text { Average regression coefficient } \\
\text { for centers }\end{array}$ & & & $-0.05333 * *$ \\
\hline
\end{tabular}

1 ** Probability level of significance: 1 percent; * probability level of significance: 5 percent.

different fields collected for 1 crop only. The regression coefficients arrived at for different fields are given in table 3. Here also, all of the fields showed the detrimental effect of infestation, with more than half of them showing a significant difference from zero. Although the coefficient varied from about -0.0050 to -0.089 on testing for homogeneity, no significant differences were found. Hence, after elimination of the variation due to the difference 


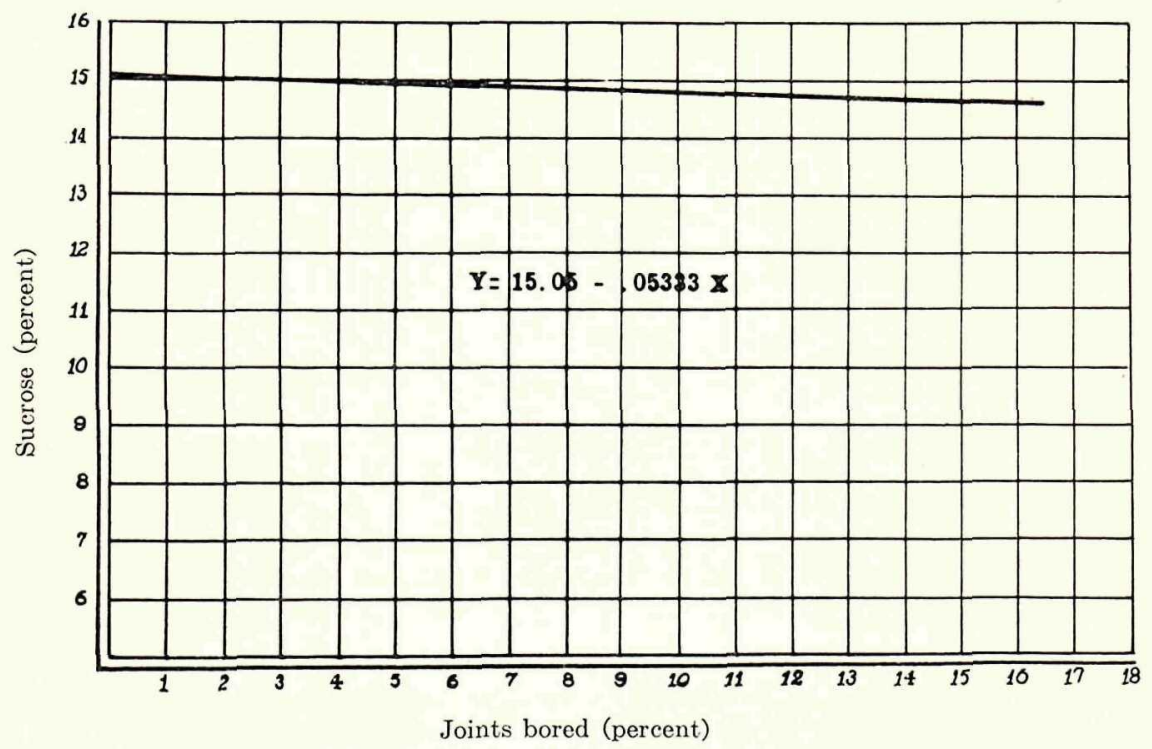

Frg. 3.-Line of regression of available sucrose in centers of cane on percentage infestation by moth-borers.

in the fields, the average regression equation was obtained as:

$$
Y=15.05-0.05333 X
$$

where $Y=$ percentage of available sucrose in centers of cane, and $X=$ percentage of borer infestation in centers.

The regression coefficient was highly significant too. Figure 3 shows the estimated line plotted to fit the data for centers.

\section{Bases}

For the study of sucrose reduction, if any, in the bases of the cane, 200 samples (10 bases per sample or around 2,000 bases) of 1 crop collected at random from 16 fields, were available. Estimation equations were computed for these fields having regression coefficients presented in table 4. Here again the coefficients for different fields did not show enough evidence of difference among themselves, even though they ranged from about $-0.0 \mathrm{C} 67$ to -0.375 , all showing detrimental effects of infestation. The average regression equation obtained after eliminating field differences, was:

$$
Y=14.67-0.02573 X
$$

where $Y=$ percentage of available sucrose in bases of canes, and $X=$ percentage of borer infestation in bases. 
TABLE 4.-Regression coefficients for samples from sugarcane bases

\begin{tabular}{|c|c|c|c|}
\hline Field identification No. & Regression coefficient ${ }^{1}$ & $\begin{array}{l}\text { Field identification } \\
\text { No. }\end{array}$ & Regression coefficient ${ }^{1}$ \\
\hline 6 & -0.02752 & 24 & -0.04093 \\
\hline 8 & $.04019^{*}$ & 25 & .01328 \\
\hline 9 & .01254 & 26 & $.06435^{*}$ \\
\hline 13 & .01692 & 28 & .02661 \\
\hline 14 & $.03747^{* *}$ & 29 & .006715 \\
\hline 17 & .01979 & 31 & .01218 \\
\hline 20 & .02943 & 32 & .01582 \\
\hline 22 & .05237 & 33 & $.2696^{*}$ \\
\hline $\begin{array}{l}\text { Average regression coefficient } \\
\text { for bases }\end{array}$ & & & $-0.002573^{* *}$ \\
\hline
\end{tabular}

1** Probability level of significance: 1 percent; * probability level of significance: 5 percent.

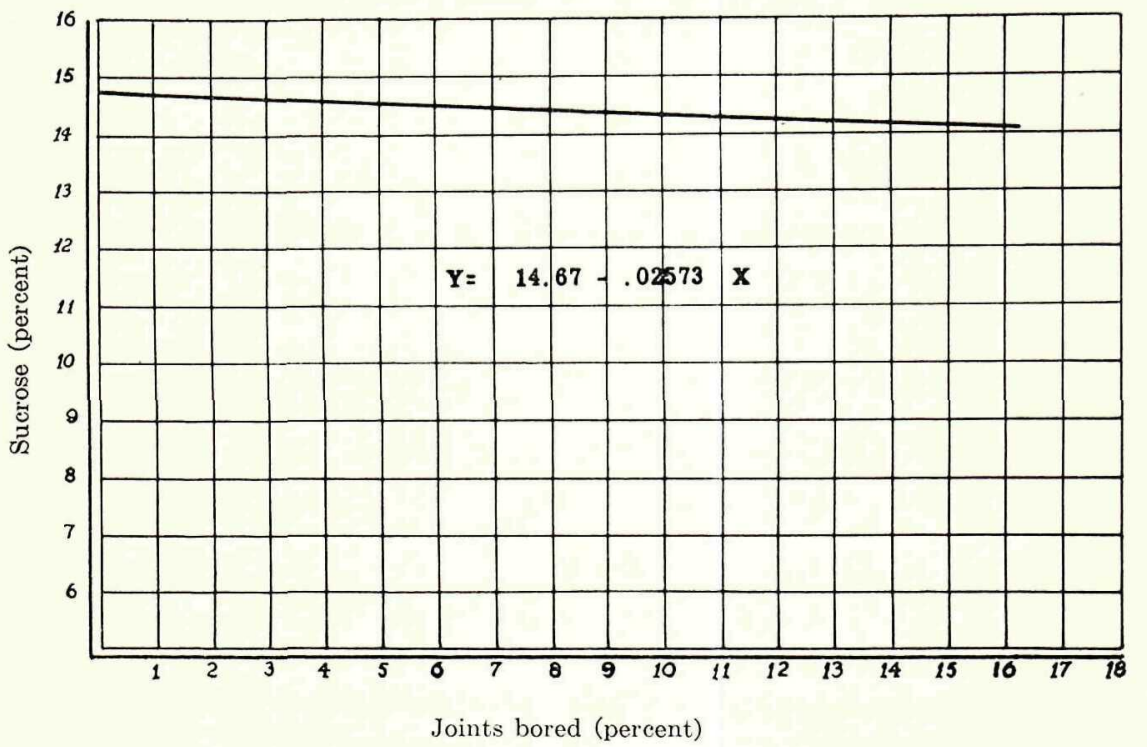

FIG. 4.-Line of regression of available sucrose in bases of cane on percentage infestation by moth-borers.

The line is shown plotted in figure 4 . Although only 4 out of the 16 coefficients for fields showed significant detrimental effects, the average regression was found to be highly significant.

OBSERVATIONS AND ECONOMIC IMPLICATIONS OF FINAL RESULTS

This study on the direct losses of or reduction in available sucrose caused by the sugarcane moth-borer is a preliminary attempt to develop a sound 
basis for figuring the damage to our sugarcane growers caused by this insect. It is our aim to continue these investigations on a larger scale. The work as published is not final, since there is great opportunity for further research.

From the study made separately for each of the classifications discussed above it was found that infestation reduced the normal available sucrose content of the cane in all four, the effect being greatest in the center portion of the stalk and least in the base. The effect was found always to be very remarkable in that the regression coefficients showed highly significant differences from the zero value.

For practical purposes and for actual application of the study in fieldwork we shall consider only the factor of average reduction of sucrose content as established in the study of whole canes in which healthy and bored canes were used. Thus, a reduction of 0.03549 percent of available sucrose was found per 1 percent of joint infestation caused by moth-borer. If this factor is multiplied by the percentage of joint infestation in any area, and the result is multiplied again by the average tons of cane produced per acre, one is able to obtain the loss of available sucrose in tons per acre. If the result is then multiplied by 2,000 , the loss is obtained in pounds of sugar lost per acre. If the price of sugar per pound was then multiplied by the pounds lost per acre one obtained the loss in dollars per acre and consequently in any given area. Calculated thus, the losses caused by mothborer attack in Colonia Juana Díaz, at Santa Isabel, Puerto Rico (property of Luce \& Co.) during the years 1950, 1951 and 1952 are shown in table 5 .

The losses for the 3 years amounted to $\$ 49,326$ for that Colonia only. This figure will give an idea of how much money is lost every year by the sugarcane industry from the direct damage of this insect to sugarcane juices, independently of other damage it produces.

The exact figure for the average joint infestation for Puerto Rico is

TABLE 5.-Sugar production and estimated losses caused by moth-borer infestation of cane at Colonia Juana Diaz, Santa Isabel, P. R., 1950-52

\begin{tabular}{c|c|c|c|c|c|c|c}
\hline $\begin{array}{c}\text { Harvest } \\
\text { period }\end{array}$ & $\begin{array}{c}\text { Area } \\
\text { harvested }\end{array}$ & $\begin{array}{c}\text { Cane } \\
\text { per acre }\end{array}$ & $\begin{array}{c}\text { Average } \\
\text { price } \\
\text { of sugar } \\
\text { per pound }\end{array}$ & $\begin{array}{c}\text { Joint infes- } \\
\text { tation } \\
\text { (average } \\
\text { for year) }\end{array}$ & $\begin{array}{c}\text { Loss of } \\
\text { sucrose } \\
\text { per acre }\end{array}$ & $\begin{array}{c}\text { Total loss } \\
\text { of sucrose } \\
\text { in the year }\end{array}$ & $\begin{array}{c}\text { Total } \\
\text { loss }\end{array}$ \\
\cline { 1 - 3 } & Acres & Tons & Cents & Percent & Pounds & Tons & Dollars \\
1950 & 872 & 42.75 & 5.931 & 9.01 & 273.60 & 119.29 & 14,150 \\
1951 & 742 & 51.42 & 6.057 & 8.49 & 309.60 & 114.86 & 13,914 \\
1952 & 866 & 56.83 & $6.00^{2}$ & 10.14 & 409.18 & 177.18 & 21,262 \\
\hline
\end{tabular}

${ }^{1}$ Information courtesy of M. S. Baker, Agricultural Research Department, Luce \& Co., Aguirre, P. R.

2 Approximate price of sugar per pound in N. Y. market (average for year 1952). 
TABLe 6.-Estimated Puerto Rican sugar production and losses caused by moth-borer infestation, 1940-51

\begin{tabular}{c|c|c|c|c|c|c}
\hline $\begin{array}{c}\text { Harvest } \\
\text { period }\end{array}$ & $\begin{array}{c}\text { Total area } \\
\text { harvested }\end{array}$ & $\begin{array}{c}\text { Cane }{ }^{1} \text { per } \\
\text { acre }\end{array}$ & $\begin{array}{c}\text { Average price } \\
\text { of sugar per } \\
\text { pound }\end{array}$ & $\begin{array}{c}\text { Loss of } \\
\text { sucrose per } \\
\text { acre }\end{array}$ & $\begin{array}{c}\text { Total loss } \\
\text { of sucrose } \\
\text { in the year }\end{array}$ & $\begin{array}{c}\text { Total annual } \\
\text { loss }\end{array}$ \\
\cline { 1 - 2 } & Acres & Tons & Cents & Pounds & Tons & Dollars \\
1940 & 252,969 & 34.77 & 2.786 & 222.12 & $28,094.74$ & $1,565,439$ \\
1941 & 236,296 & 32.78 & 3.378 & 209.40 & $24,740.19$ & $1,671,447$ \\
1942 & 307,612 & 32.54 & 3.739 & 207.88 & $31,973.19$ & $2,390,955$ \\
1943 & 310,225 & 27.94 & 3.740 & 178.48 & $27,684.48$ & $2,070,799$ \\
1944 & 280,353 & 19.98 & 3.743 & 127.64 & $17,894.93$ & $1,339,614$ \\
1945 & 288,617 & 27.70 & 3.750 & 176.96 & $25,536.83$ & $1,915,262$ \\
1946 & 303,307 & 24.85 & 4.589 & 158.74 & $24,073.48$ & $2,209,464$ \\
1947 & 325,211 & 28.55 & 6.217 & 182.38 & $29,655.99$ & $3,687,426$ \\
1948 & 336,285 & 28.37 & 5.545 & 181.24 & $30,474.15$ & $3,379,583$ \\
1949 & 353,385 & 31.12 & 5.807 & 198.80 & $35,126.47$ & $4,079,588$ \\
1950 & 367,093 & 28.91 & 5.931 & 184.68 & $33,897.37$ & $4,020,906$ \\
1951 & 366,404 & 28.66 & 6.057 & 183.09 & $33,541.72$ & $4,063.244$ \\
\hline
\end{tabular}

${ }^{1}$ Figures for the years 1940 to 1948, obtained from the Annual Book of Statistics of P. R., fiscal year 1949-50, Economic Development Administration, Office of Economic Research, San Juan, P. R. Figures for 1949-51, from Annual Reports for 1950-51 and 1952, of the Caribbean Office, Production and Marketing Administration, U. S. Department of Agriculture, San Juan, P. R.

unknown. However, if we take 9 percent as a general average on the basis of acres of sugarcane harvested in tons of cane per acre, and the average price of sugar for the years 1940 to 1951, the losses of sucrose caused by the insect can be estimated. The figures are shown in table 6 .

The total value loss of sucrose amounted to $\$ 32,393,727$ for the period between 1940 and 1951, or an average yearly loss of about $\$ 2,500,000$. The figures are comparable to the losses obtained in the State of Louisiana, although the percentage of borer infestation there is estimated to be twice as large as that for Puerto Rico.

Considering the losses caused by this pest to the sugarcane industry, every effort should be made to prevent them. We are still actively seeking measures for the control of this important inser't pest.

\section{SUMMARY}

More than 1,000 samples of stalks of sugarcane were milled and their juices analyzed in attempting to obtain a more accurate estimate of the losses caused by infestation of sugarcane in Puerto Rico by the moth stalk-borer, Diatraea saccharalis (Fabricius). The samples were divided into (1) whole-canes unbored, (2) whole-canes bored, (3) tops unbored, (4) tops bored, (5) central portions unbored, (6) central portions bored, (7) bases unbored, and (8) bases bored. 
The statistical analyses showed that the highest percentage of sucrose in cane is found in the central portion, less is found at the base, and the least in the top joints.

By using a factor of 0.03549 (as determined by the junior author), which represents the loss of available sucrose per 1 percent of joint infestation, one can calculate the losses of sucrose caused by moth-borer damage in any given area.

Thus it was found that Colonia Juana Díaz, near Santa Isabel, P. R. had an estimated total loss of $\$ 49,326$ in the 3 years 1950,1951 , and 1952 , from borer injury. It is estimated that the average annual losses in Puerto Rico amounted to approximately $\$ 2,500,000$ in the 12 -year period from 1940 to 1951.

\section{RESUMEN}

Con el fin de estimar con mayor precisión los daños que causa el taladrador del tallo de la caña, Diatraea saccharalis (Fabricius), en Puerto Rico, se molieron más de mil muestras de caña de azúcar cuyos jugos fueron debidamente analizados. Las muestras se dividieron en ocho grupos, a saber: (1) cañas enteras sanas, (2) cañas enteras taladradas, (3) canutos superiores del tallo sanos, (4) canutos superiores del tallo taladrados, (5) canutos centrales del tallo sanos, (6) canutos centrales del tallo taladrados, (7) canutos inferiores del tallo sanos, y (8) canutos inferiores del tallo taladrados.

El análisis estadístico demostró que el porcentaje más alto de sacarosa en la caña se encuentra en la parte central del tallo, es menos en la base y aún menos en la parte superior del tallo.

Se determinó que el factor de 0.03549 , que representa la périda de sacarosa aprovechable por cada por ciento de infestación (basado en el por ciento de canutos taladrados) puede usarse para calcular los daños que causa este insecto en cualquier zona cañera de Puerto Rico. Por lo tanto, se estimó que la Colonia Juana Díaz, de la Central Cortada, en Santa Isabel, P. R., tuvo un pérdida en total para los años 1950, 1951, y 1952, de $\$ 49,326$ como consecuencia de los daños causados por el taladrador del tallo. El promedio de los daños causados por este insecto en Puerto Rico durante los últimos 12 años, 1940-1951, inclusive, se estima en $\$ 2,500,000$ anuales.

\section{LITERATURE CITED}

1. Barber, T. C., Damage to sugarcane in Louisiana by the sugarcane borer, (Diatraea saccharalis Fab.) Circular 139, Bureau of Entomology, U.S.D.A., Washington, D. C., pp. 7-12, 1911.

2. Ingram, J. W. et al., The sugarcane situation in Louisiana, Sugar J. 12(12) 121950.

3. Ingram, J. W. and Dugas, A. L., Losses resulting from sugarcane-borer injury to sugarcane in 1945, Sugar Bull. 25(2) 10-1 1946. 
4. López Tuero, Fernando, La caña de azúcar en Puerto Rico, su cultivo y enfermedad, Imp. El Bol. Merc. 123 San Juan, P. R., 1895.

5. Salinas, J. G., Atención al borer, Publicación de la Estación Experimental, Central Gómez Mena, San Nicholás, P., Habana, Cuba, 1950.

6. Stubbs, W. C. and Morgan H. A., Sugarcane borer moth (Diatraea saccharalis), Bull. 70, second series, Louisiana Agricultural Experiment Station, 1902.

7. Van Dine, D. L., Damage to sugarcane juice by the moth stalk-borer (Diatraea saccharalis Fabr.) Circular No. 1, Experiment Station of the Sugar Producer's Association of Puerto Rico, (English edition), 1-11 1912. 